\title{
ANALISIS PENGARUH KECEPATAN ALIRAN FLUIDA DINGIN TERHADAP EFEKTIVITAS SHELL AND TUBE HEAT EXCHANGER
}

\author{
Ahmad Husen', Tubagus M. Ichwan Akbar ${ }^{2}$, Nur Cholis ${ }^{3}$ \\ Program Studi Teknik Mesin, Institut Sains dan Teknologi Nasional, Jakarta Selatan ${ }^{1,2}$ \\ Program Studi Teknik Mesin, Universitas Pembangunan Nasional Veteran Jakarta, Jakarta Selatan ${ }^{3}$ \\ Email²: tbichwan091097@gmail.com
}

\begin{abstract}
Abstrak
Sebagai penukar panas di mana suhu fluida tinggi mengalir ke suhu fluida yang lebih rendah, penukar panas diharapkan memiliki efektivitas yang besar. Secara teoritis peningkatan kecepatan aliran akan meningkatkan nilai efektivitas dan dapat memperbesar bilangan Reynold dan bilangan Nusselt yang kemudian meningkatkan perpindahan panas oleh koveksi. Pengujian ini dilakukan secara konveksi paksa dengan memvariasikan kecepatan fluida dingin ( $\mathrm{Vc}$ ) yakni $1,19 \mathrm{~m} / \mathrm{s}$ hingga $2,91 \mathrm{~m} / \mathrm{s}$ dengan kecepatan fluida panas yang konstan $(\mathrm{Vh})=1,98 \mathrm{~m} / \mathrm{s}$ pada temperatur fluida panas masuk $(\mathrm{Th}, 1)=60^{\circ} \mathrm{C}$ dan temperatur fluida dingin $(\mathrm{Tc}, 1)=32^{\circ} \mathrm{C}$ yang dibuat konstan. Dari hasil penelitian didapat karakteristik dari suatu alat penukar kalor naik seiring dengan kenaikan kecepatan fluida dingin. Karakteristik alat penukar kalor antara lain yaitu bilangan Reynold (Re), bilangan Nusselt ( $\mathrm{Nu}$ ), koefisien konveksi (h), koefisien konveksi menyeluruh (U), perpindahan panas (q), dan efektivitas $(\varepsilon)$. Dimana didapat karakteristik paling optimal pada kecepatan fluida dingin $(\mathrm{Vc})=2,91 \mathrm{~m} / \mathrm{s}$ dan minimum pada kecepatan fluida dingn $(\mathrm{Vc})=1,19 \mathrm{~m} / \mathrm{s}$ maka didapat bahwa kenaikan kecepatan aliran fluida dingin dapat meningkatkan kinerja atau efektivitas suatu alat penukar kalor. Namun kenaikan efektivitas ini tidak berlangsung terus dimana akan sampai dititik dimana efektivitas tidak naik lagi melainkan turun. Dimana pada kecepatan fluida dingin $(\mathrm{Vc})=1,19 \mathrm{~m} / \mathrm{s}$ dapat menyerap panas hingga temperatur fluida dingin naik sampai $44,7^{\circ} \mathrm{C}$ dan sampai pada kecepatan $(\mathrm{Vc})=2,91 \mathrm{~m} / \mathrm{s}$ kenaikan temperatur fluida dingin hanya sampai $41,6^{\circ} \mathrm{C}$ karena waktu kontak kedua semakin singkat membuat penyerapan kalor fluida panas semakin singkat, maka jika kecepatan fluida dingin dinaikan terus menerus akan membuat penyerapan kalor dari fluida panas turun yang berakibat efektivitas alat penukar kalor akan turun.
\end{abstract}

Kata kunci: Kecepatan Aliran Fluida Dingin, Alat Penukar Panas Shell and Tube, Efektivitas

\begin{abstract}
As a heat exchanger where high fluid temperatures flow to lower fluid temperatures, a heat exchanger is expected to have great effectiveness. Theoretically the increase in flow velocity will increase the value of effectiveness and can enlarge the Reynold numbers and Nusselt numbers which then increase the heat transfer by covection. This test is performed by forced convection by varying the speed of the cold fluid $(V c)$ which is $1.19 \mathrm{~m} / \mathrm{s}$ to $2.91 \mathrm{~m} / \mathrm{s}$ with a constant hot fluid velocity $(\mathrm{Vh})=1.98 \mathrm{~m} / \mathrm{s}$ at the temperature of the incoming hot fluid $(\mathrm{Th}, 1)$ $=60^{\circ} \mathrm{C}$ and cold fluid temperature $(T c, 1)=32^{\circ} \mathrm{C}$ which is made constant. From the results of the study obtained the characteristics of a heat exchanger increases with the increase in the speed of cold fluid. Characteristics of heat exchangers include Reynold numbers (Re), Nusselt numbers $(\mathrm{Nu})$, convection coefficients $(h)$, overall convection coefficients $(U)$, heat transfer $(q)$, and effectiveness ( $(\varepsilon)$. Where is obtained the most optimal characteristics at cold fluid velocity $(V c)=2.91 \mathrm{~m} / \mathrm{s}$ and minimum cold fluid velocity $(V c)=1.19 \mathrm{~m} / \mathrm{s}$, it is found that increasing the speed of cold fluid flow can increase the performance or effectiveness of a device heat exchanger. but this increase in effectiveness does not go on where it will reach a point where the effectiveness does not increase but decreases. Where the cold fluid velocity $(\mathrm{Vc})=1.19 \mathrm{~m} / \mathrm{s}$ can absorb heat until the temperature of the cold fluid rises to $44.7^{\circ} \mathrm{C}$ and until the speed $(V c)=$
\end{abstract}


$2.91 \mathrm{~m} / \mathrm{s}$ the increase in temperature of cold fluid is only up to $41.6^{\circ} \mathrm{C}$ because the shorter contact time makes the heat absorption of the hot fluid shorter, then if the speed of the cold fluid is increased continuously it will make the absorption of heat from the hot fluid go down which results in the effectiveness of the heat exchanger going down.

Keywords: Cold Fluid-Flow Speed, Shell and Tube Heat Exchanger, Effectiveness.

\section{PENDAHULUAN}

\section{Latar Belakang Masalah}

Dalam berbagai kehidupan manusia seharihari aplikasi perpindahan apanas memiliki kotribusi yang tidak sedikit. Perangkat yang digunakan sebagai transformasi energi adalah penukar panas atau yang disebut penukar panas. Penerapannya sangat luas, terutama untuk industri pengolahan makanan, minuman, dan industri lainnya. Heat exchanger banyak digunakan diberbagai industri untuk proses pertukaran kalor, sehingga heat exchanger mempunyai peran yang sangat penting dalam suatu proses produksi pada industri. Shell and tube banyak digunakan karena memiliki beberapa keuntungan salah satunya konstrusinya sederhana, kokoh, kemudahan dari segi perawatan dan terhitung ekonomis.

Komponennya terdiri dari sebuah shell silindris dibagian luar dan sejumlah tube dibagian dalam, dimana temperatur fluida di luar tube (di dalam shell) dan di dalam tube berbeda, sehingga terjadi perpindahan panas antara fluida diluar tube dan didalam tube. Dalam pengaplikasian nya shell and tube ini dilapangan masih banyak permasalahan yang ditimbulkan, misalnya panas yang di transfer masih belum maksimal atau terjadi penurunan tekanan yang membuat kerja pompa menjadi berat, hal ini berindikasi pada kerusakan pada pompa dan tingginya biaya untuk listrik dan perawatannya.

Pada penelitian ini akan dijelaskan bagaimana pengaruh kenaikan kecepatan aliran fluida dinginnya dengan kecepatan fluida panas konstan terhadap efektivitasnya dengan alat penukar kalor shell and tube skala laboratorium jika kecepatan alirannya ditingkatkan terusmenerus untuk mendapatkan nilai maksimum efektivitasnya, hingga efektivitas tidak naik kembali melainkan turun.

\section{Tujuan Penelitian}

Tujuan penelitian ini adalah untuk menganalisis pengaruh kecepatan aliran fluida dingin untuk mencari efektivitas tertinggi seiring dengan kenaikan kecepatan aliran sampai suatu besaran tertentu hingga kemudian efektivitas yang dihasilkan tidak naik lagi melainkan turun.

\section{TINJAUAN PUSTAKA}

\section{Shell and tube heat exchanger}

Shell and tube heat exchanger merupakan jenis penukar panas yang paling banyak digunakan dalam industri perminyakan. Alat ini terdiri dari sebuah shell (tabung/silindris besar) seperti yang terlihat pada gambar 2.1 dibawah ini.

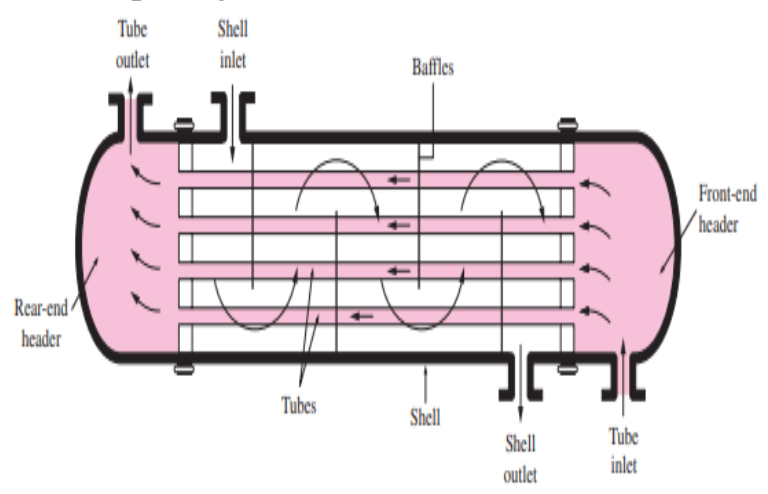

Gambar 2.1. Shell and Tube Heat Exchanger

\section{Jenis Aliran Dalam Shell and Tube Heat \\ Exchanger \\ a. Parallel flow (Aliran Searah)}

Aliran searah terjadi ketika arah aliran dua cairan dalam penukar panas sejajar. Ini berarti bahwa kedua cairan memasuki satu sisi dan keluar dari sisi lainnya, mengalir dalam arah yang sama. Karakter dari jenis penukar panas ini adalah bahwa suhu energi yang menyediakan cairan akan selalu lebih tinggi daripada yang menerima energi dari saat memasuki penukar panas sampai keluar, seperti tergambar pada gambar 2.2. (Za Tendra, 2011)

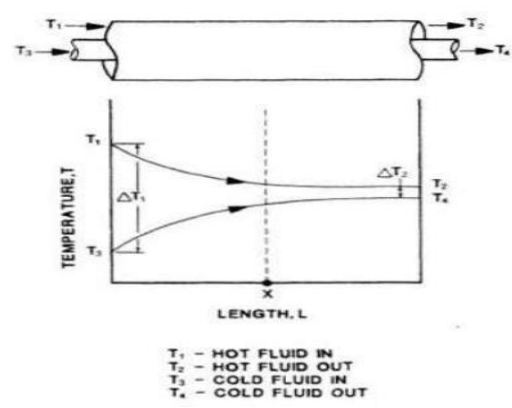

Gambar 2.2. Tipe aliran searah dan profil temperatur 
Dengan kesetimbangan panas maka diperoleh besarnya perbedaaan temperatur suhu rata-rata fluida adalah:

$$
\mathrm{LMTD}_{\mathrm{pf}}=\frac{\Delta T 1-\Delta T 2}{\ln \left(\frac{\Delta T 1}{\Delta T 2}\right)}=\frac{(\operatorname{th1} 1-t c 1)-(t h 2-t c 2)}{\ln \frac{(t h 1-t c 1)}{(t h 2-t c 2)}}
$$

(G.F.Hewitt,G.L.Shires,T.R.Bott, 1994)

b. Counter flow (Aliran Berlawanan Arah)

Terlihat pada gambar 2.3 bahwa aliran berlawanan arah adalah arah berlawanan dari aliran, di mana satu fluida masuk di ujung penukar panas, sedangkan fluida lain masuk di ujung lain dari penukar panas, yang masing-masing mengalir dalam arah berlawanan. Untuk jenis aliran arus balik ini memberikan panas yang lebih baik bila dibandingkan dengan aliran langsung atau paralel. Sementara jumlah lintasan mempengaruhi efektivitas penukar panas yang digunakan. (Za Tendra, 2011)

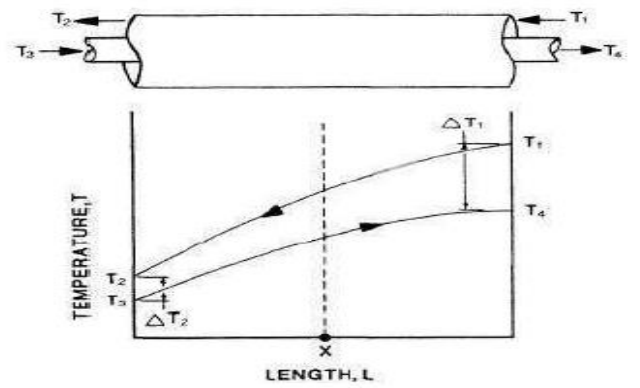

$$
\begin{aligned}
& T_{1}=\text { HOT FLUID IN } \\
& T_{2}=\text { HOT FLUID OUT } \\
& T_{3}=\text { COLD FLUID IN } \\
& T_{4}=\text { COLD FLUID OUT }
\end{aligned}
$$

Gambar 2.3. Tipe aliran berlawanan arah dan profil temperatur

Dengan kesetimbangan panas maka diperoleh besarnya perbedaaan temperatur suhu rata-rata fluida adalah :

$\mathrm{LMTD}_{\mathrm{cf}}=\frac{\Delta T 1-\Delta T 2}{\ln \left(\frac{\Delta T 1}{\Delta T 2}\right)}=\frac{(\operatorname{th1} 1-\operatorname{tc} 2)-(\operatorname{th} 2-\operatorname{tc} 1)}{\ln \frac{(\operatorname{th} 1-\operatorname{tc} 2)}{(\operatorname{th} 2-\operatorname{tc} 1)}}$

(G.F.Hewitt,G.L.Shires,T.R.Bott, 1994)

\section{c. Cross flow (Aliran Silang)}

Crross-flow atau sering disebut dengan aliran silang pada gambar 2.4 adalah apabila fluidafluida yang mengalir sepanjang permukaan bergerak dalam arah saling tegak lurus. (Za Tendra, 2011)

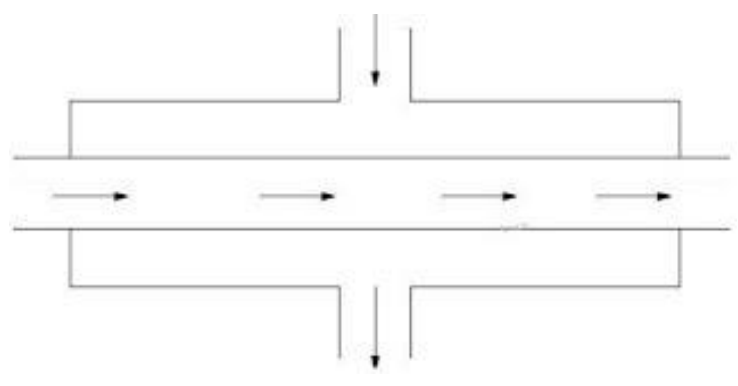

Gambar 2.4. Tipe aliran cross flow (silang)

Pada aliran ini, besarnya beda temperatur rata-rata adalah besarnya LMTD aliran berlawanan dikalikan besarnya faktor koreksi. Besarnya faktor koreksi diberikan sesuai dengan bentuk dari kontruksi saluran dimana dua fluida yang berbeda temperatur mengalir.

$\mathrm{LMTD}=\mathrm{F}_{\mathrm{t}} \times \mathrm{LMTD}_{\mathrm{cf}}$

(G.F.Hewitt,G.L.Shires,T.R.Bott, 1994)

Faktor koreksi $\left(\mathrm{F}_{\mathrm{t}}\right)$ untuk konfigurasi aliran silang didapat dengan membandingkan dua temperatur rasio $\mathrm{P}$ dan $\mathrm{R}$ yang didefiniskan sebagai :

$P=\frac{t c 2-t c 1}{t h 1-t c 1}$

$\mathrm{R}=\frac{t h 1-t h 2}{t c 2-t c 1}$

(G.F.Hewitt,G.L.Shires,T.R.Bott, 1994)

\section{Persamaan Perhitungan}

Deep flow bukanlah aliran bebas sehingga kita membutuhkan alternatif. Kecepatan fluida dalam pipa berubah dari nol di permukaan karena tidak ada slip, hingga kecepatan maksimum di tengah pipa. Dimana kecepatan aliran didalam pipa dapat diketahui dengan persamaan:

$V=\frac{Q}{A}$

(Bruce R Munson, 2009)

Disisi lain, untuk menghitung perpindahan kalor pada suatu alat penukar kalor membutuhkan laju aliran massa. Persamaan untuk menghitung laju aliran massa, yakni:

$\dot{\mathrm{m}}=\rho \cdot V \cdot A$

(J.P. Holman, 2010)

Dan laju aliran massa volumetrik didefinisikan sebagai berikut:

$G=\frac{\dot{m}}{a}=\rho \cdot V$

(J.P. Holman, 2010) 
Dimana untuk menentukan laju aliran massa volumetrik memerlukan luas daerah aliran (flow area) dengan persamaan:

Flow area untuk sisi tube:

$a t=N t \frac{A}{n}$

(G.F.Hewitt,G.L.Shires,T.R.Bott, 1994)

Flow area untuk sisi shell:

$a s=\frac{D_{i} \cdot C^{\prime} \cdot L b}{P t}$

(G.F.Hewitt,G.L.Shires,T.R.Bott, 1994)

$R e=\frac{\rho . V \cdot D i}{\mu}=\frac{G \cdot D i}{\mu}$

(J.P. Holman, 2010)

Dimana diameter untuk sisi shell digunakan persamaan diameter hidraulik $\left(\mathrm{D}_{\mathrm{h}}\right)$ diameter untuk bentuk penampang saluran tempat fluida itu mengalir tidak bulat maka kolerasi perpindahan kalor itu didasarkan atas diameter hidraulik $\left(D_{h}\right)$ yang didefinisikan dengan persamaan:

$\mathrm{D}_{\mathrm{h}=\frac{4 \cdot \mathrm{A}}{\mathrm{P}}}$

(G.F.Hewitt,G.L.Shires,T.R.Bott, 1994) Tetapi diamter hidraulik untuk susuan Square pitch menggunakan persamaan:

$D_{h}=\frac{4\left(P t^{2}-\frac{\pi D o t^{2}}{4}\right)}{\pi \cdot D o t}$

(G.F.Hewitt,G.L.Shires,T.R.Bott, 1994)

Dimana $\mathrm{D}_{\text {ot }}$ adalah diamter luar tube. Dan untuk susunan Triangular pitch menggunakan persamaan :

$D_{h}=\frac{4\left(\frac{P t}{2} \times 0,86 . P t-\frac{1}{2}\left(\frac{\pi D o t^{2}}{4}\right)\right)}{\pi \frac{D o t}{2}}$

(G.F.Hewitt,G.L.Shires,T.R.Bott, 1994)

Angka Reynolds digunakan sebagai kriteria untuk menunjukan apakah aliran dalam tabung atau pipa itu laminar atau turbulen dimana:

$\operatorname{Re}<2300$

$2000 \leq \mathrm{Re} \leq 4000$

$\operatorname{Re}>4000$
Aliran Laminar

Aliran Transisi

Aliran Turbulen

(J.P. Holman, 2010)

$\mathrm{Nu}=1,86(\operatorname{Re} \operatorname{Pr})^{1 / 3}\left(\frac{D}{L}\right)^{1 / 3}\left(\frac{\mu}{\mu_{W}}\right)^{0,14}$

(J.P. Holman, 2010)

\section{METODE DAN PENGOLAHAN DATA \\ Diagram Alir Penelitian}

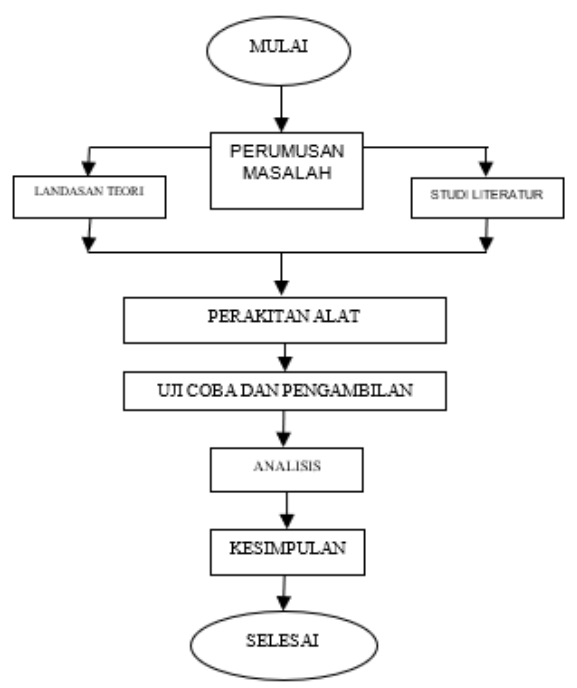

Gambar 3.1. Diagram Alir Penelitian

\section{Variabel Penelitian}

Adapun variabel penelitian dibedakan atas variabel bebas yakni kecepatan fluida dingin $\left(\mathrm{V}_{\mathrm{c}}\right)$ dan variabel terikat yakni karakteristik alat penukar kalor yaitu bilangan Reynold (Re), Bilangan Nusselt $(\mathrm{Nu})$, perpindahan kalor $(\mathrm{q})$, koefisien perpindahan panas (h), koefisien perpindahan panas menyeluruh (U), dan efektivitas $(\varepsilon)$.

\section{Alat Pengujian}

Tabel 3.1 Spesifikasi Shell

\begin{tabular}{ll}
\hline Shell & Keterangan \\
\hline Diameter luar & $0,12 \mathrm{~m}$ \\
\hline Tebal & $0,005 \mathrm{~m}$ \\
\hline Diameter dalam & $0,11 \mathrm{~m}$ \\
\hline Jumlah baffle & 13 \\
\hline Jarak antar baffle & $0,044 \mathrm{~m}$ \\
\hline Jenis baffle & Double Segmental \\
\hline Jumlah laluan aliran & 1 \\
\hline Bahan shell & Acrylic \\
\hline
\end{tabular}

Tabel 3.2. Spesifikasi Tube

\begin{tabular}{|c|c|}
\hline Tube & Keterangan \\
\hline Diameter luar & $0,006 \mathrm{~m}$ \\
\hline Tebal & $0,0015 \mathrm{~m}$ \\
\hline Diameter dalam & $0,003 \mathrm{~m}$ \\
\hline Panjang tube & $0,65 \mathrm{~m}$ \\
\hline Jumlah tube & 48 \\
\hline Susunan pitch & Triangular tube \\
\hline Tube pitch & $0,01 \mathrm{~m}$ \\
\hline Jumlah laluan aliran & 1 \\
\hline Bahan tube & $\begin{array}{lr}\text { Stainless } & \text { Steel } \\
\text { ASTM } & \text { A269 } \\
\text { grade } 316 / 316 L\end{array}$ \\
\hline
\end{tabular}


Peralatan lain seperti terlihat pad tabel 3.3:

Tabel 3.3. Spesifikasi pompa air

\begin{tabular}{ll}
\hline Pompa & Keterangan \\
\hline Merk Pompa & Shimizu PS-116 BIT \\
\hline Daya listrik & $125 \mathrm{Watt}$ \\
\hline Daya start listrik & $250 \mathrm{Watt}$ \\
\hline Kapasitas & 24 liter/menit \\
\hline Daya Hisap & $6 \mathrm{~m}$ \\
\hline Daya Dorong & $21 \mathrm{~m}$ \\
\hline
\end{tabular}

\section{Prosedur Penelitian}

Tahapan yang dilakukan dalam penelitian ini adalah sebagai berikut:

1) Masukan fluida panas dan fluida dinign pada masing-masing resevoir.

2) Menyalakan Water Heater untuk memanaskan fluida panas sampai mencapai suhu yang diperlukan yaitu $60^{\circ} \mathrm{C}$ dan untuk fluida dingin dibuat sampai suhu $32{ }^{\circ} \mathrm{C}$ di buat konstan.

3) Menyalakan pompa air dan mengatur bukaan valve sesuai dengan debit aliran yang diperlukan agar air dapat mengalir masuk kedalam heat exchanger. Debit aliran fluida panas pada sisi tube dibuat konstan yaitu 15 liter/menit dan fluida dingin 22 liter/menit selanjutnya menunggu kondisi operasi steady state.

4) Setelah mencapai posisi steady maka perubahan temperatur fluida keluar pada thermometer dicatat dengan jangka waktu 60 detik dan di ulangi sebanyak 3 kali.

5) Menghentikan pompa dan mendinginkan instalasi penelitian dan pengulangan pada langkah ke-2 dengan merubah debit aliran fluida dingin menjadi 18 liter/menit, 15 liter/menit, 12 liter/menit, dan 9 liter/menit.

\section{Data Hasil Pengujian}

Dimana fluida panas memasuki tabung dan fluida dingin memasuki shell dengan mengatur suhu input fluida panas $60{ }^{\circ} \mathrm{C}$ dan fluida dingin $32{ }^{\circ} \mathrm{C}$. Maka hasil eksperimen adalah sebagai berikut:

Tabel 3.4. Data hasil pengujian

\begin{tabular}{ccccccc}
\hline No & $\begin{array}{c}\text { Debit } \\
\text { Tube } \\
(\text { LPM })\end{array}$ & $\begin{array}{c}\text { Debit } \\
\text { Shell } \\
(\text { LPM })\end{array}$ & $\begin{array}{c}\text { Th,in } \\
\left({ }^{\circ} \mathrm{C}\right)\end{array}$ & $\begin{array}{c}\text { Tc,in } \\
\left({ }^{\circ} \mathrm{C}\right)\end{array}$ & $\begin{array}{c}\text { Th,out } \\
\left({ }^{\circ} \mathrm{C}\right)\end{array}$ & $\begin{array}{c}\text { Tc,out } \\
\left({ }^{\circ} \mathrm{C}\right)\end{array}$ \\
\hline \multirow{2}{*}{1} & \multirow{2}{*}{15} & 9 & 60 & 32 & 51,1 & 45 \\
\cline { 4 - 7 } & \multirow{2}{*}{15} & \multirow{2}{*}{12} & 60 & 32 & 50,9 & 44,5 \\
\cline { 3 - 6 } & \multirow{2}{*}{15} & 60 & 32 & 51,1 & 44,6 \\
\hline
\end{tabular}

\begin{tabular}{|c|c|c|c|c|c|c|}
\hline & & & 60 & 32 & 48,9 & 43,6 \\
\hline \multirow{3}{*}{3} & \multirow{3}{*}{15} & \multirow{3}{*}{15} & 60 & 32 & 47,8 & 43,2 \\
\hline & & & 60 & 32 & 48,1 & 43,4 \\
\hline & & & 60 & 32 & 47,9 & 43,3 \\
\hline \multirow{3}{*}{4} & \multirow{3}{*}{15} & \multirow{3}{*}{18} & 60 & 32 & 46,8 & 42,3 \\
\hline & & & 60 & 32 & 47 & 42,7 \\
\hline & & & 60 & 32 & 46,9 & 42,2 \\
\hline \multirow{3}{*}{5} & \multirow{3}{*}{15} & \multirow{3}{*}{22} & 60 & 32 & 46,2 & 42 \\
\hline & & & 60 & 32 & 46,1 & 42,7 \\
\hline & & & 60 & 32 & 45,6 & 40,1 \\
\hline
\end{tabular}

Maka didapatkan nilai rata-rata dari pengujian tersebut sebagai berikut:

Tabel 3.5. Data rata-rata hasil pengujian

\begin{tabular}{ccccccc}
\hline No & $\begin{array}{c}\text { Debit } \\
\text { Tube } \\
(\text { LPM })\end{array}$ & $\begin{array}{c}\text { Debit } \\
\text { Shell } \\
(\text { LPM })\end{array}$ & $\begin{array}{c}\text { Th,in } \\
\left({ }^{\circ} \mathrm{C}\right)\end{array}$ & $\begin{array}{c}\text { Tc,in } \\
\left({ }^{\circ} \mathrm{C}\right)\end{array}$ & $\begin{array}{c}\text { Th,out } \\
\left({ }^{\circ} \mathrm{C}\right)\end{array}$ & $\begin{array}{c}\text { Tc,out } \\
\left({ }^{\circ} \mathrm{C}\right)\end{array}$ \\
\hline 1 & 15 & 9 & 60 & 32 & 51 & 44,7 \\
\hline 2 & 15 & 12 & 60 & 32 & 48,8 & 43,7 \\
\hline 3 & 15 & 15 & 60 & 32 & 47,9 & 43,3 \\
\hline 4 & 15 & 18 & 60 & 32 & 46,9 & 42,4 \\
\hline 5 & 15 & 22 & 60 & 32 & 45,96 & 41,6 \\
\hline
\end{tabular}

\section{Perhitungan Data}

Menentukan Kecepatan Aliran (V)

Untuk menemukan kecepatan aliran yang masuk ke penukar panas shell dan tube, kecepatan aliran untuk fluida panas adalah:

Dimana,

$\mathrm{Q}=15$ liter $/$ menit $=0,25$ liter $/$ detik $=2,5 \times 10^{-4}$ $\mathrm{m}^{3} /$ detik

$\mathrm{D}=0,0127 \mathrm{~m}$

Maka,

$V_{h}=\frac{2,5 \times 10^{-4}}{\frac{3,14 \times(0,0127)^{2}}{4}}=1,98 \mathrm{~m} / \mathrm{s}$

Dan untuk kecepatan aliran fluida dingin adalah:

Dimana,

$\mathrm{Q}=22$ liter $/$ menit $=0,36$ liter $/$ detik $=3,6 \times 10^{-4}$ $\mathrm{m}^{3} /$ detik

Maka,

$V_{c}=\frac{3,6 \times 10^{-4}}{\frac{3,14 \times(0,0127)^{2}}{4}}=2,91 \mathrm{~m} / \mathrm{s}$

Menentukan Laju Aliran Massa (m)

Untuk mendapatkan laju aliran massa yang masuk ke shell and tube heat exchanger, maka laju aliran massa fluida panas adalah:

$\dot{\mathrm{m}}_{\mathrm{h}}=983,3 \times 1,98 \times 1,26 \times 10^{-4}=0,245 \mathrm{~kg} / \mathrm{s}$

Dan laju aliran massa fluida dingin sebagai berikut: $\dot{\mathrm{m}}_{\mathrm{c}}=994,9 \times 2,91 \times 1,26 \times 10^{-4}=0,365 \mathrm{~kg} / \mathrm{s}$

Menentukan Perpindahan Kalor Fluida (q) 
Untuk menetukan perpindahan kalor fluida dimana besar kalor yang dilepas oleh fluida panas adalah:

$$
\begin{aligned}
\mathrm{q}_{\mathrm{h}} & =0,245 \times 4179 \times\left(60^{\circ} \mathrm{C}-45,96^{\circ} \mathrm{C}\right) \\
& =14374,9 \mathrm{~J} / \mathrm{s}=14374,9 \text { Watt }
\end{aligned}
$$

Dan untuk besar kalor yang diserap fluida dingin adalah:

$$
\begin{aligned}
\mathrm{q}_{\mathrm{c}} & =0,365 \times 4174 \times\left(41,6^{\circ} \mathrm{C}-32^{\circ} \mathrm{C}\right) \\
& =14625,7 \mathrm{~J} / \mathrm{s}=14625,7 \text { Watt }
\end{aligned}
$$

\section{Menetukan nilai LMTD $\left(\Delta \mathrm{T}_{\mathrm{m}}\right)$} digunakan:

Untuk mencari perbedaan suhu rata-rata maka

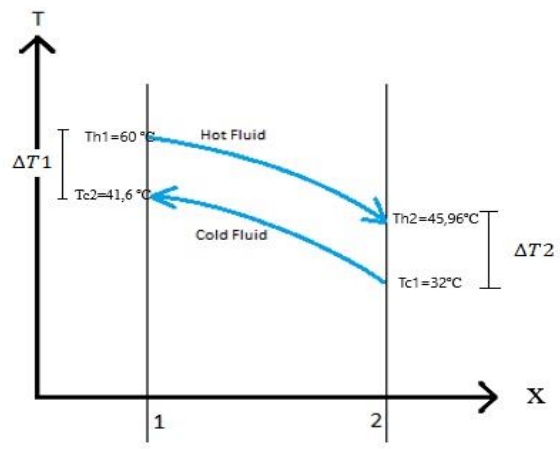

Gambar 3.2. Diagram LMTD aliran berlawanan arah

$\mathrm{LMTD}_{\mathrm{cf}}=\frac{\left(60^{\circ} \mathrm{C}-41,6^{\circ} \mathrm{C}\right)-\left(45,96^{\circ} \mathrm{C}-32^{\circ} \mathrm{C}\right)}{\ln \frac{\left(60^{\circ} \mathrm{C}-41,6^{\circ} \mathrm{C}\right)}{\left(45^{\circ}, 96^{\circ} \mathrm{C}-32^{\circ} \mathrm{C}\right)}}=16,08^{\circ} \mathrm{C}$

Jadi, $\Delta \mathrm{T}_{\mathrm{m}}=\mathrm{F}_{\mathrm{t}} \mathrm{x} \mathrm{LMTD}_{\mathrm{cf}}$

Maka, $\Delta \mathrm{T}_{\mathrm{m}}=1 \times 16,08^{\circ} \mathrm{C}$

$=16,08^{\circ} \mathrm{C}$

\section{Mencari Koefisien Panas dalam pipa $(h$, in)}

Untuk mencari koefisien perpindahan panas di dalam pipa kita harus mencari luas flow area pada sisi tube terlebih dahulu maka digunakanlah persamaan:

Luas flow area pada sisi tube:

$$
a t=48 \frac{\frac{3.14 \times(0,003)^{2}}{4}}{1}=3,3912 \times 10^{-4} \mathrm{~m}^{2}
$$

Dan untuk mencari jenis aliran dalam tube kita harus menentukan laju aliran massa volumetrik pada tube dengan persamaan:

$$
G=\frac{0,245}{3,3912 \times 10^{-4}}=722,46 \mathrm{~kg} / \mathrm{m}^{2} . \mathrm{s}
$$

Menentukan jenis aliran didalam tube maka digunakan persamaan:

$$
R e=\frac{722,46 \times 0,003}{4,71 \times 10^{-4}}=4601,7
$$

Re > 4000 maka aliran didalam tube adalah Turbulen

Karena aliran didalam tube adalah aliran turbulen untuk itu menentukan bilangan Nusselt maka digunakan persamaan:

$$
\begin{aligned}
& \mathrm{Nu}=0,023 \times(4601,7)^{0,8} \times(3,01)^{0,3}=27,27 \\
& h, \text { in }=\frac{27,27 \times 0,654}{0,003}=5944,86 \mathrm{~W} / \mathrm{m}^{2} .{ }^{\circ} \mathrm{C}
\end{aligned}
$$

\section{Mencari Koefisien Panas Luar pipa (h, o)}

Untuk mencari koefisien perpindahan panas diluar pipa kita harus mencari luas flow area pada sisi shell terlebih dahulu, maka luas flow area pada sisi shell adalah:

$$
\text { as }=\frac{0,11 \times(0,01-0,006) \times 0,044}{0,01}
$$

Dan untuk menentukan laju aliran massa volumetrik pada shell digunakan persamaan:

$$
G=\frac{0,365}{1,936 \times 10^{-3}}=188,53 \mathrm{~kg} / \mathrm{m}^{2} . s
$$

Aliran didalam shell adalah aliran transisi, namun didalam shell terdapat baffle. Untuk itu menentukan bilangan Nusselt maka digunakan persamaan:

$$
\begin{aligned}
& N u=0,023 \times(2945,78)^{0,8} \times(5,14)^{0,4}=26,39 \\
& h, o=\frac{26,39 \times 0,622}{0,012}=1367,88 \mathrm{~W} / \mathrm{m}^{2} \cdot{ }^{\circ} \mathrm{C}
\end{aligned}
$$

\section{Menentukan Koefisien Perpindahan Panas Menyeluruh (U)}

Untuk menentukan koefisien perpindahan panas menyeluruh makan digunakan persamaan:

$U=\frac{1}{\frac{1}{h_{i}}+\frac{\ln \left(\frac{r 0}{r i}\right)}{2 \pi k L}+\frac{1}{h_{o}}}$

(G.F.Hewitt,G.L.Shires,T.R.Bott, 1994)

Untuk konduktifitas thermal pipa adalah $(\mathrm{k})=16,3$ $\mathrm{W} / \mathrm{m} .{ }^{\circ} \mathrm{C}$.

Maka,

$$
\begin{aligned}
U=\frac{1}{\frac{1}{5944,86}+}+\frac{\ln \left(\frac{0,003}{0,0015}\right)}{2 \times 3,14 \times 16,3 \times 0,65}+\frac{1}{1367,88} \\
=88,50 \mathrm{~W} / \mathrm{m}^{2} \cdot{ }^{\circ} \mathrm{C}
\end{aligned}
$$


Menentukan Efektivitas Shell and Tube Heat Exchanger $(\varepsilon)$

Untuk menentukan laju kapasitas kalor menggunakan persamaan:

$c_{h}=0,245 \times 4179$

$=1023,9 \mathrm{~J} / \mathrm{s}{ }^{\circ} \mathrm{C}=1023,9 \mathrm{~W} /{ }^{\circ} \mathrm{C}$

Dan untuk fluida dingin dalam shell

$c_{\mathrm{c}}=0,365 \times 4174$

$=1523,51 \mathrm{~J} / \mathrm{s}{ }^{\circ} \mathrm{C}=1523,51 \mathrm{~W} /{ }^{\circ} \mathrm{C}$

Untuk menentukan perpindahan kalor maksimum maka digunakan lah persamaan:

$\mathrm{q}_{\text {maks }}=1023,9\left(60{ }^{\circ} \mathrm{C}-32{ }^{\circ} \mathrm{C}\right)=28669,2$ Watt

Dan untuk menentukan perpindahan kalor aktual kita menggunakan persamaan:

$\mathrm{q}_{\text {act }}=\mathrm{q}_{\mathrm{h}}=\mathrm{q}_{\mathrm{c}}$

$\mathrm{q}_{\mathrm{h}}=0,245 \times 4179 \times\left(60^{\circ} \mathrm{C}-45,96^{\circ} \mathrm{C}\right)$

$=14374,9 \mathrm{~J} / \mathrm{s}=14374,9 \mathrm{Watt}$

Maka efektivitas untuk shell and tube heat exchanger adalah:

$\varepsilon=\frac{14374,9}{28669,2}=0,501 \times 100 \%=50 \%$

Menentukan Pengaruh Kecepatan Fluida Dingin Terhadap Efektivitas Dengan Analisis Regresi dan Korelasi Sederhana

Berdasarkan hasil perhitungan data penelitian tentang pengaruh kecepatan fluida dingin ( $x$ ) terhadap efektivitasnya (y) adalah sebagai berikut:

Tabel 3.6. Pengaruh kecepatan fluida dingin terhadap efektivitas

\begin{tabular}{|c|c|c|c|c|c|}
\hline $\begin{array}{l}\mathrm{N} \\
\mathrm{o}\end{array}$ & $\begin{array}{c}\text { Kecepata } \\
\text { n Fluida } \\
\text { dingin } \\
(\mathrm{m} / \mathrm{s}) \\
\left(\mathrm{x}_{\mathrm{i}}\right)\end{array}$ & $\begin{array}{c}\text { Efekti } \\
\text { vitas } \\
(\%) \\
\left(\mathrm{yi}_{\mathrm{i}}\right)\end{array}$ & $x_{i}^{2}$ & $\mathrm{yi}^{2}$ & $\mathrm{x}_{\mathrm{i} .} \mathrm{y}_{\mathrm{i}}$ \\
\hline 1 & 1,19 & 33,9 & 1,42 & 1149,21 & 40,341 \\
\hline 2 & 1,59 & 41,7 & 2,53 & 1738,89 & 66,303 \\
\hline 3 & 1,98 & 43 & 3,92 & 1849 & 85,14 \\
\hline 4 & 2,38 & 46 & 5,66 & 2116 & 109,48 \\
\hline 5 & 2,91 & 50 & 8,47 & 2500 & 145,5 \\
\hline $\begin{array}{l}\mathrm{K} \\
= \\
5\end{array}$ & $\begin{array}{c}S_{x}= \\
10,05\end{array}$ & $\begin{array}{c}S_{y}= \\
214,6\end{array}$ & $\begin{array}{c}\mathrm{SS}_{\mathrm{x}}= \\
22\end{array}$ & $\begin{array}{c}\mathrm{SS}_{\mathrm{y}}= \\
9353,1\end{array}$ & $\begin{array}{c}S p_{x y}= \\
446,76 \\
4\end{array}$ \\
\hline
\end{tabular}

maka persamaan regresinya didapatkan:

$Y=25,6985+8,5679 x_{i}$

Maka didapat kan nilai regresinya adalah:
Tabel 3.7. Hasil perhitungan nilai regresi

\begin{tabular}{ccc}
\hline $\begin{array}{c}\text { Kecepatan Fluida } \\
\text { dingin }(\mathrm{m} / \mathrm{s}) \\
\left(\mathrm{x}_{\mathrm{i}}\right)\end{array}$ & $\begin{array}{c}\text { Efektivitas }(\%) \\
\left(\mathrm{y}_{\mathrm{i}}\right)\end{array}$ & $\mathrm{Y}=\mathrm{a}_{\mathrm{o}}+\mathrm{b} \mathrm{\textrm {x } _ { \mathrm { i } }}$ \\
\hline 1,19 & 33,9 & 35,89 \\
\hline 1,59 & 41,7 & 39,32 \\
\hline 1,98 & 43 & 42,66 \\
\hline 2,38 & 46 & 46,09 \\
\hline 2,91 & 50 & 50,63 \\
\hline
\end{tabular}

\section{ANALISIS DAN PEMBAHASAN \\ Data Perhitungan Hasil Pengujian}

Tes ini dilakukan dengan konveksi paksa dengan memvariasikan kecepatan fluida dingin $(\mathrm{Vc})$ yaitu $1,19 \mathrm{~m} / \mathrm{s}$ hingga $2,91 \mathrm{~m} / \mathrm{s}$ dengan kecepatan fluida panas konstan $(\mathrm{Vh})=1,98 \mathrm{~m} / \mathrm{s}$ pada suhu panas yang masuk fluida $(\mathrm{Th} 1)=60^{\circ} \mathrm{C}$ dan suhu fluida dingin $(\mathrm{Tc} 1)=32^{\circ} \mathrm{C}$ yang dibuat konstan.

\section{Pengaruh Kecepatan Fluida Dingin Terhadap Penurunan Temperatur}

Analisis penurunan temperatur dihitung dengan memvariasikan kecepatan fluida dingin dengan kecepatan $1,19 \mathrm{~m} / \mathrm{s}, 1,59 \mathrm{~m} / \mathrm{s}, 1,98 \mathrm{~m} / \mathrm{s}$, $2,38 \mathrm{~m} / \mathrm{s}$, dan $2,91 \mathrm{~m} / \mathrm{s}$ dengan kecepatan fluida panas konstan $1,98 \mathrm{~m} / \mathrm{s}$ pada temperatur masuk fluida panas $60^{\circ} \mathrm{C}$ dan temperatur fluida dingin $32^{\circ} \mathrm{C}$ yang dibuat konstan maka didapatkan hasil sebagai berikut.

Dapat dilihat pada gambar 4.1 memperlihatkan bahwa semakin besar kecepatan fluida dingin $\left(\mathrm{V}_{\mathrm{c}}\right)$ pada kecepatan fluida panas dan temperatur masuk fluida panas dan dingin konstan. Dapat dilihat bawah kenaikan kecepatan fluida dingin maka temperatur keluar fluida panas $\left(\mathrm{T}_{\mathrm{h}, 2}\right)$ semakin kecil dan temperatur keluar fluida dingin $\left(\mathrm{T}_{\mathrm{c}, 2}\right)$ juga semakin kecil akibat kecepatan fluida dingin yang cepat membuat kontak kedua fluida semakin singkat.

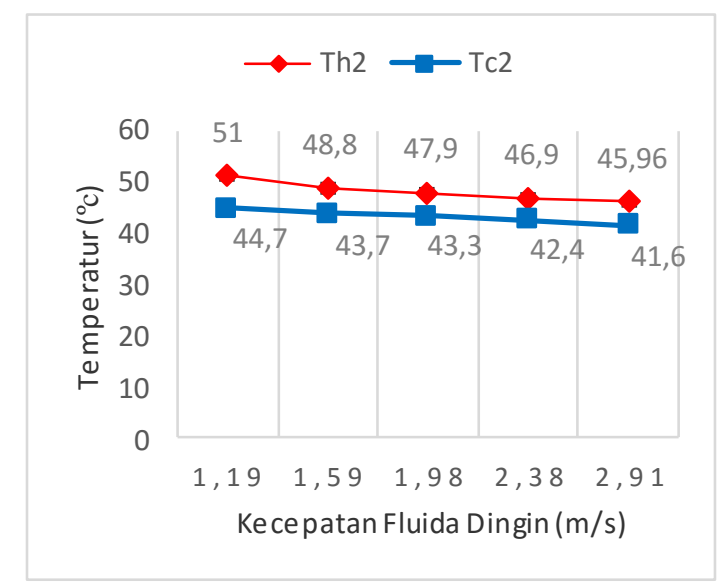

Gambar 4.1. Grafik data perubahan temperatur 


\section{Pengaruh Kecepatan Fluida Dingin Terhadap Perpindahan Panas}

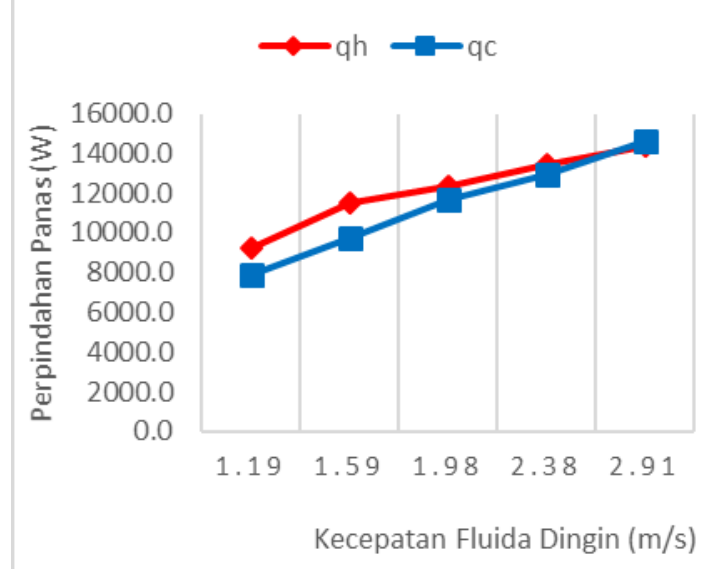

Gambar 4.2. Grafik data perubahan perpindahan panas

Pada gambar 4.2 dapat dilihat bahwa semakin besar kecepatan fluida dingin $\left(\mathrm{V}_{\mathrm{c}}\right)$ pada kecepatan fluida panas dan temperatur masuk fluida panas dan dingin konstan. Kenaikan kecepatan fluida maka perpindahan panas pun semakin tinggi juga, tetapi sesuai dengan persamaannya perpindahan panasnya juga dipengaruhi oleh perbedaan suhu fluida yang masuk dan keluar semakin tinggi perbedaan suhu nya maka semakin tinggi pula perpindahan panasnya dan sebaliknya semakin kecil perbedaan suhu masuk dan keluarnya maka semakin kecil pula perpindahan panasnya.

\section{Pengaruh Kecepatan Fluida Dingin Terhadap Bilangan Reynold dan Nusselt}

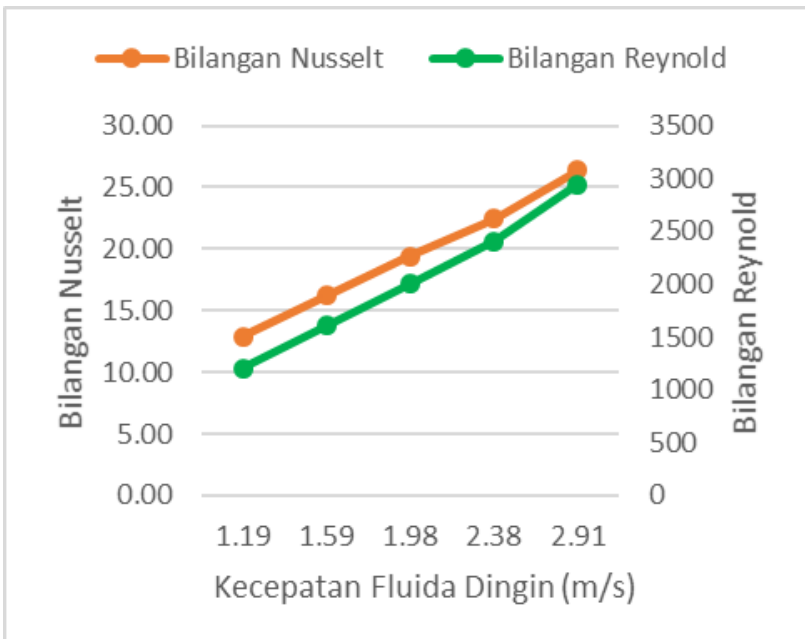

Gambar 4.3. Grafik data perubahan bilangan Reynold dan Nusselt

Gambar 4.3 dilihat bahwa peningkatan bilangan Reynold (Re) mencapai optimal pada kecepatan fluida dingin $\left(\mathrm{V}_{\mathrm{c}}\right)=2,91 \mathrm{~m} / \mathrm{s}$ dan pada kecepatan $\left(\mathrm{V}_{\mathrm{c}}\right)=1,19 \mathrm{~m} / \mathrm{s}$ bilangan Reynold mendapatkan nilai minimum.

\section{Pengaruh Kecepatan Fluida Dingin Terhadap Koefisien Perpindahan Panas}

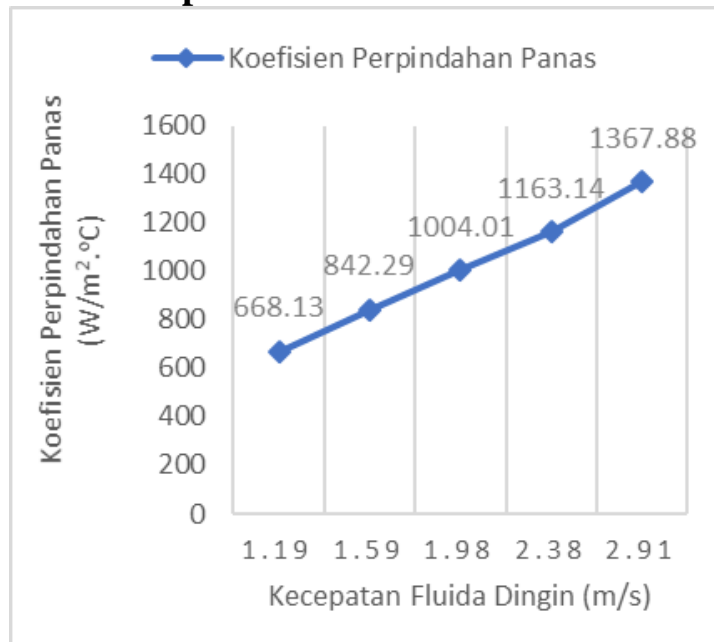

Gambar 4.4. Grafik data perubahan koefisien perpindahan panas

Pada gambar 4.4 memperlihatkan pada kecepatan $\left(\mathrm{V}_{\mathrm{c}}\right)=2,91 \mathrm{~m} / \mathrm{s}$ adalah koefisien perpindahan panas paling besar dan pada kecepatan $\left(\mathrm{V}_{\mathrm{c}}\right)=1,19 \mathrm{~m} / \mathrm{s}$ koefisien perpindahan panas nya paling kecil.

\section{Pengaruh Kecepatan Fluida Dingin Terhadap} Koefisien Perpindahan Panas Menyeluruh

Gambar 4.5 menunjukkan bahwa semakin besar kecepatan fluida dingin $(\mathrm{Vc})$ pada kecepatan fluida

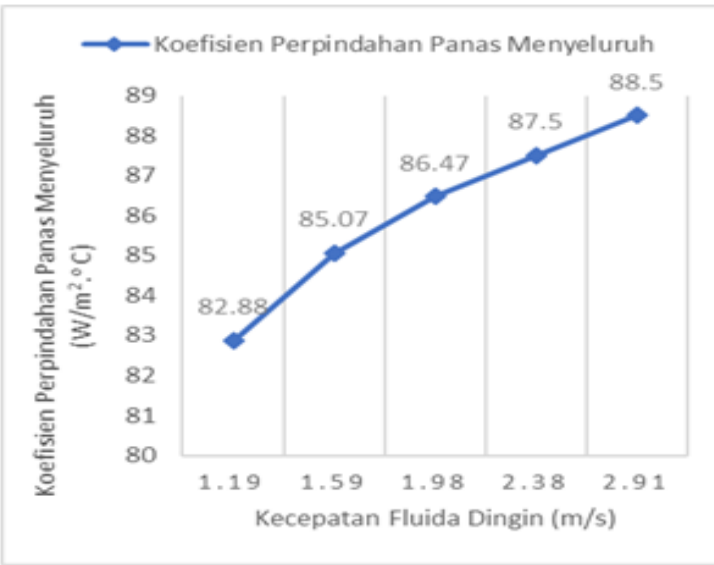

Gambar 4.5. Grafik data perubahan koefisien perpindahan panas menyeluruh

panas dan suhu fluida panas dan dingin yang masuk konstan. Dengan demikian, koefisien perpindahan panas (U) keseluruhan meningkat. Pada kecepatan $\left(\mathrm{V}_{\mathrm{c}}\right)=2,91 \mathrm{~m} / \mathrm{s}$ koefisien perpindahan panas menyeluruh paling optimal dan pada kecepatan $\left(\mathrm{V}_{\mathrm{c}}\right)$ $=1,19 \mathrm{~m} / \mathrm{s}$ koefisien perpindahan panas menyeluruh paling kecil. 


\section{Pengaruh Kecepatan Fluida Dingin Terhadap Efektivitas Shell and Tube Heat Exchanger}

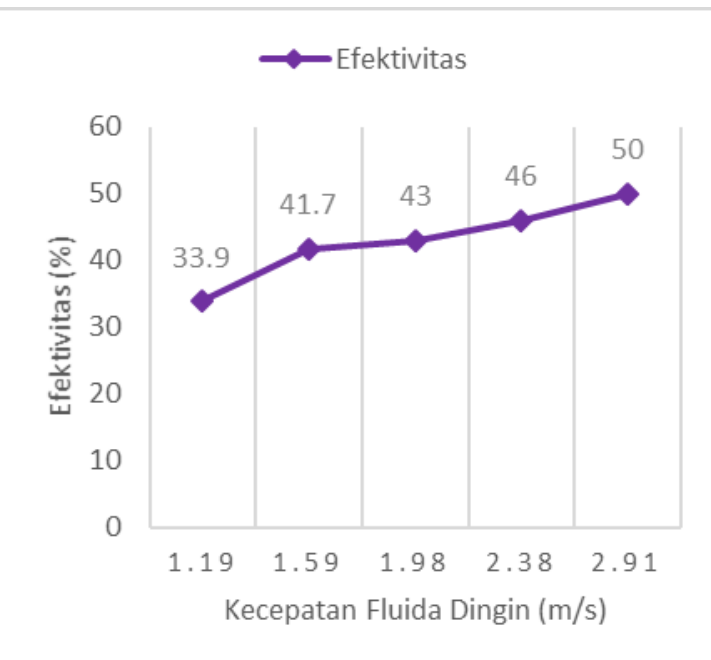

Gambar 4.6. Grafik data perubahan efektivitas

Dari gambar 4.6 didapat hasil pengujian bahwa semakin besar kecepatan fluida dingin $\left(\mathrm{V}_{\mathrm{c}}\right)$ pada kecepatan fluida panas dan temperatur masuk fluida panas dan dingin konstan. Maka, semakin besar juga efektivitas nya dimana efektivitas terbesar terjadi pada kecepatan $\left(\mathrm{V}_{\mathrm{c}}\right)=2,91 \mathrm{~m} / \mathrm{s}$ dan efektivitas terkecil terjadi pada kecepatan $\left(\mathrm{V}_{\mathrm{c}}\right)=$ $1,19 \mathrm{~m} / \mathrm{s}$ dimana efektivitas ini dipengaruhi oleh perpindahan panas kedua fluida.

\section{Pengaruh Kecepatan Fluida Dingin Terhadap Efektivitas Dengan Menggunakan Analisis Regresi dan Korelasi Sederhana}

Dimana untuk mendapatkan nilai korelasi yang mana didapatkan nilai korelasinya adalah 0,9629 mendekati 1 , artinya hubungan atau keterkaitan antara kenaikan kecepatan fluida dan efektivitas sangat kuat dan terkorelasi positif yang mana jika variabel bebas $(\mathrm{x})$ atau kenaikan kecepatan fluida $(\mathrm{Vc})$ naik maka variabel terikat $(\mathrm{y})$ atau efektivitas $(\varepsilon)$ akan naik.

Pada gambar 4.7 dimana nilai regresi mengalami perbedaan sedikit dengan nilai efektivitas aktualnya karena analisis regresi ini bersifat non-stokastik yang mana pendugaan atau penaksiran yang dilakukan dihitung secara teoritis dan mengabaikan faktor ketidakpastian.

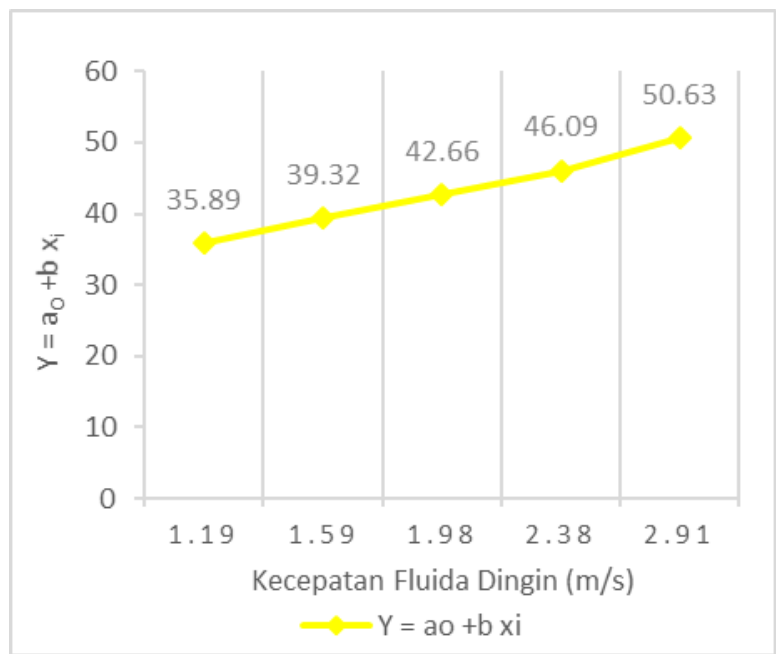

Gambar 4.7. Grafik nilai regresi

\section{SIMPULAN}

Berdasarkan hasil perhitungan dapat disimpulkan sebagai berikut:

1. Nilai karakteristik alat penukar kalor didapat paling optimum pada kecepatan fluida dingin $(\mathrm{Vc})=2,91 \mathrm{~m} / \mathrm{s}$ dan minimum pada kecepatan fluida dingn $(\mathrm{Vc})=1,19 \mathrm{~m} / \mathrm{s}$ maka didapat ke naikan kecepatan aliran fluida dingin $(\mathrm{Vc})$ meningkatkan nilai karakteristik yang meningkatkan kinerja atau efektivitas $(\varepsilon)$ suatu alat penukar kalor dari 33,9\% menjadi $50 \%$.

2. Pada kecepatan fluida dingin $(\mathrm{Vc})=1,19 \mathrm{~m} / \mathrm{s}$ fluida dingin dapat menyerap panas hingga temperatur keluar fluida dingin (Tc,2) naik sampai $44,7^{\circ} \mathrm{C}$ dan sampai pada kecepatan fluida dingin $(\mathrm{Vc})=2,91 \mathrm{~m} / \mathrm{s}$ penyerapan panas fluida dingin turun hingga temperatur keluar fluida dingin $(\mathrm{Tc}, 2)$ hanya naik sampai 41,6 ${ }^{\circ} \mathrm{C}$, maka jika kecepatan fluida dingin dinaikan terus menerus akan membuat kontak kedua fluida semakin singkat yang berakibat penurunan suhu fluida panas turun yang artinya akan membuat temperatur keluar fluida panas (Th,2) akan naik, yang mengakibatkan efektivitas (E) suatu alat penukar kalor akan turun.

3. Terjadi selisih temperatur antara fluida masuk dan keluar menurun yang mengakibatkan turunnya efektivitas shell and tube heat exchanger.

\section{DAFTAR PUSTAKA}

Afandi, Nurlan. 2018. "Simulasi Performasi Heat Exchanger Tipe Shell And Tube Dengan Helical Baffle Dan Disk And Doughnut Baffle”. Jurnal Teknik Mesin. Vol. 6 No. 1, 2018, 61-68. 
Cengel, Y.A., 2003, Heat Transfer A Practical Aproach, 2nd ed, McGraw-Hill, New York.

Handoyo, Ekadewi Anggraini. 2001. "Pengaruh penggunaan baffle pada shell and tube heat exchanger". Jurnal Teknik Mesin Vol. 3, No.1,April 2001: 19-23.

Hewitt, G.F., Shires, G.L., Bott, T.R., 1994, Process Heat Transfer, pp.747-776, CRC Press Inc. Boca Raton, Florida, USA.

Holman, J. P., 2010, Heat Transfer, Tenth Edition-10th Edition, McGraw-Hill. USA.3. McCabe, W., Smith, J.C., and Harriot, P., 1993, "Unit Operation of Chemical Engineering", McGraw Hill Book, Co., United States of America.

Ikhsan, Muhammad, 2012. Makalah Alat-Alat Heat Exchanger. Diakses dari http://beckfk.blogspot.com/2012/05/alat-heatexchanger.html.

Incropera, F.P., DeWitt, D.P., 2011, Fundamentals of Heat and Mass Transfer, Seventh Edition, John Wiley \& Sons, Singapore.

Kern, D. Q., 1983, Process Heat Transfer, International Student Edition Mc Graw Hill Book Co. Inc., New York.

Morris, M. 2011. Mechanical Design Of Heat Exchanger. Diakses dari http://beckfk.blogspot.com/2012/05/alat-heatexchanger.html.

Munson, Bruce R., Donald F. Young, Theodore H. Okiishi, Wade W. Huebsch. 2009. Fundamentals of Fluid Mechanics 6th Edition. Amerika: John Wiley \& Sons, Inc.

Rochim, Taufiq. 2001. Spefisikasi Metrologi dan Kontrol Kualitas Geometrik, ITB, Bandung.

TEMA, 2007, Standards of the Tubular Exchanger Manufacturers Association, 9th ed., TEMA, Inc., New York.

Tendra Za. 2011. Heat Exchanger. Diakses dari http://www.scribd.com/doc/88048057/Heat. Exchanger

Wibawa Dwi Sukma, Indra. 2012. Heat Eexchanger. Lampung : Jurusan Teknik Kimia Universitas Negeri Lampung.

Yang, Jian Feng. 2014." International Journal of Heat and Mass Transfer". Xi'an: Xi'an Jiaotong University, China. 